\title{
Competencies of Tribal Leaders on their Aboriginal Leadership Functions and the Effectiveness of the Certificate of Ancestral Domain Title as an Empowerment Tool in the Ancestral Domain of the Ayangans in Nueva Vizcaya, Philippines
}

\author{
Marcelino T. Razalan Jr. ${ }^{1}$ \\ ${ }^{1}$ Nueva Vizcaya State University, Bayombong, Nueva Vizcaya, 3700, Philippines \\ Email: marazalan[at]yahoo.com
}

\begin{abstract}
The study aimed to determine the relationships between the tribal leaders' competencies on their aboriginal leadership functions and the effectiveness of the Certificate of Ancestral Domain Title (CADT) as an empowerment tool in the ancestral domain of the Ayangans. The study was undertaken in the selected barangays of the three municipalities of Nueva Vizcaya where the Ayangan has established their ancestral domain. There were 308 households who served as the respondents of the study selected through systematic random sampling. The result indicated tribal leaders were moderately capable in performing their executive, legislative and judicial leadership functions. Likewise, the CADT was moderately effective as an empowerment tool in terms of the recognition of ancestral domain, social justice, cultural integrity, and self-governance. The data further denoted that the leadership capability of the tribal leaders and the effectiveness of the CADT as an empowerment tool are significantly and positively correlated inferring a direct relationship between the variables.
\end{abstract}

Keywords: ancestral domain, Ayangans, empowerment, governance, aboriginal leadership

\section{Introduction}

The recognition of "ownership" over ancestral domain is necessary to provide legal protection for Indigenous Cultural Communities (ICC) in their claims on natural resources against outside forces, especially state interventions and large-scale commercialization (Mendoza and Brett, 2012). The approval of the Indigenous Peoples Right Act of 1997 (IPRA) opened a new era for Indigenous People (IPs) in the governance of their ancestral domains, their territories and their communities. The issuance of Certificate of Ancestral Domain Title (CADT) formalizes and gives rights to an ICC, to control land, air and sea resources, to stay in their territory and regulate the entry of migrants within their ancestral domain (NCIP, 2007).

Aware of the provisions of the IPRA, the Ayangans submitted their application for the issuance of CADT to the National Commission on Indigenous People (NCIP) on July 25,2005 . Upon compliance with all the provisions of the Indigenous Peoples' Rights Act (IPRA), the Ayangans were able to obtain a CADT on February 2, 2007 covering $6,241.5673$ hectares, distributed in the municipalities of Villaverde, Solano and Bayombong in Nueva Vizcaya as well as in Lamut and Asipulo in Ifugao province (Osingat, 2007). The issuance of the CADT necessitated the formulation of an Ancestral Domain Sustainable Development and Protection Plan (ADSDPP). The ADSDPP is the blueprint in the management and development of the ancestral domain area and responds to the agreed vision, mission, goals and objectives of the Ayangan Tribe.

The issuance of CADT to the Ayangans, put the burden of forest management squarely on the shoulders of Ayangan communities and local government entities. This devolution process is driven by the failure of conventional state-centered management models to ensure sustainable resource management. In the context of development interventions, this failure is attributed to, among others, "the lack of coherence between interventions and local livelihood strategies and the exclusion of local people in project design, planning, implementation, monitoring and evaluation." Hence, upland communities should be empowered to manage the forest resources at their disposal to ensure sustainable management (Enters and Anderson, 2000) within their ancestral domain. If they are empowered, then a group can fully access personal/collective power, authority and influence, and to employ that strength when engaging with other people, institutions or society.

Although the Ayangans today are now looked-up from among the various IPs or ICCs in the Cagayan Valley Region because of their feat of being one of those who have legally acquired their ancestral domain, questions still remain on the leadership capability, which could affect the effectiveness of the CADT as an empowerment mechanism in the upland. Some of the basic questions include the following: Do tribal leaders have sufficient leadership capability to implement all the activities required under the CADT? With the implementation of the CADT and the leadership capabilities of the tribal leaders, how empowered are the Ayangans in their ancestral domain?

With the forgoing unanswered questions, the study was conducted to determine if tribal leaders possess the appropriate aboriginal leadership capability as well as the effectiveness of the Certificate of Ancestral Domain Title as an empowerment tool in the ancestral domain. The result 


\section{International Journal of Science and Research (IJSR) \\ ISSN (Online): 2319-7064 \\ Index Copernicus Value (2013): 6.14 | Impact Factor (2015): 6.391}

would be used to recommend measures to improve both the leadership capability of the tribal leaders and improve the effectiveness of the Certificate of Ancestral Domain Title as an empowerment tool in the ancestral domain.

\subsection{Objective}

The study aimed to determine the relationships between the tribal leaders' aboriginal tri-functional leadership competencies and the effectiveness of the Certificate of Ancestral Domain Title (CADT) as an empowerment tool in the ancestral domain of the Ayangans. Specifically, it aims to describe the ecological characteristics of the ancestral domain of the Ayangan; ascertain the demographic profile of the beneficiaries, assess the Ayangans' tribal leaders' leadership capability; determine the level of effectiveness of the of the CADT as an empowerment tool and ascertain if there is a significant relationship between leadership capability and the effectiveness of the CADT as an empowerment tool; and finally, recommend measures on improving the tribal leaders' leadership capability and the effectiveness of the CADT as an empowerment tool.

\section{Methodology}

The study used the descriptive-inferential method of research with a questionnaire as its primary data gathering tool. The study was conducted in upland barangays in the municipalities of Bayombong, Solano and Villaverde. These barangays include Cabuaan and Ipil-Cuneg in the municipality of Bayombong; barangays Cabuluan and Ocapon in Villaverde; and barangay Commonal in Solano. The respondents were asked to fill-in the information in the survey questionnaire. Key informants were guided to conduct critical analyses of their life situation and helped the researcher arrive at negotiated facts and informed opinions.

The effectiveness of CADT as a tool for IP empowerment was measured using 1-5 scales with a qualitative of very low to very high description. The level of aboriginal leadership capabilities were also measured using 1-5 scales with a qualitative description of not capable to very capable. The data were analyzed using descriptive and inferential statistics, specifically the Spearman's Rho and Pearson's r. The 0.05 probability level (level of significance) was used as the critical point of reference. Results and findings were presented in the narrative reportorial method portrayed in tabular forms.

\section{Results and Discussion}

\subsection{Ecological Characteristics of the Ancestral Domain of the Ayangans}

The ancestral domain of the Ayangans is located in (5) upland barangays: Cabuaan and Ipil-Cuneg in Bayombong; Cabuluan and Ocapon in Villaverde; and Commonal in Solano, all in the province of Nueva Vizcaya.

The ancestral domain lies in mountainous areas with elevations ranging from 600-800 meters above sea level. It has a warm to cool climate, but temperature varies in accordance with the elevation. Some rainy days are experienced during the months of December, January and February due to the influence of the northwest monsoon that passes through the area from the northeast and east. The soil type series is the Guimbalaon, found mostly in the rolling to mountainous areas. The soil is slightly to strongly acidic. Its organic matter content is very low while its saturation is high to very high. The area is utilized for primary and secondary forest as well as for upland cultivation. It is suited for the production of root crops. There are various existing land uses within the ancestral domain to include agricultural, forest, bodies of water, open space, mining and quarrying area; settlement, infrastructure and utilities, built up areas, garbage dumpsite and other uses.

\subsection{Demographic characteristics of the CADT beneficiaries}

Table 1 presents the general profile of the respondents. The average age is 42.83 years, male, dominated by members of the Ayangan tribe, married, members of tribal organizations, and mostly belonging to the Roman Catholic group and whose households have 4-6 members. In terms of educational attainment, only a little over $25 \%$ of the respondents were able to complete high school. Their main source of income is farming.

Table 1: Demographic characteristic of the CADT beneficiaries

\begin{tabular}{|c|c|c|}
\hline Indicator & Number & $\%$ \\
\hline Average Age & \multicolumn{2}{|c|}{42.83} \\
\hline Sex: Male & 137 & 44.5 \\
\hline Ethnic group: Ayangan & 286 & 92.90 \\
\hline Civil status: Married & 263 & 85.4 \\
\hline $\begin{array}{c}\text { Position in the community: Tribal } \\
\text { member }\end{array}$ & 267 & 86.7 \\
\hline $\begin{array}{c}\text { Religion: Roman Catholic } \\
\text { Highest Educational Attainment: High } \\
\text { school graduate }\end{array}$ & 140 & 45.5 \\
\hline Primary Occupation: Farming & 217 & 26 \\
\hline Average household size: 4-6 members & 144 & 40.50 \\
\hline $\begin{array}{c}\text { Organizational affiliation: CADT } \\
\text { Development Association }\end{array}$ & 306 & 99.40 \\
\hline Total number of respondents & \multicolumn{2}{|c|}{308} \\
\hline
\end{tabular}

\subsection{Aboriginal Tri-functional Leadership} Competencies of the Tribal Leaders

Three aspects of the tribal leaders' aboriginal leadership competencies were assessed in this study: executive, legislative and judicial capabilities. First, executive leadership capability was measured through their capability in planning, organizing, supervising, directing, coordinating and controlling. Second, legislative leadership capability was measured using capacity to legislate ordinances necessary to discharge duty and ordinances that promote the general welfare of the tribe. Lastly, judicial leadership capability was assessed using the following indicators: mediating conflict, chairing the Council of elders in hearing cases and bringing about acceptable, peaceful and amicable settlement, making fair judgment/decision in accordance with customary laws/constitutional laws and endorsing cases to higher court. The result of the assessment on leadership capabilities is summarized in Table 2. 


\section{International Journal of Science and Research (IJSR) ISSN (Online): 2319-7064}

Index Copernicus Value (2013): 6.14 | Impact Factor (2015): 6.391

Table 2: Aboriginal tri-functional leadership competencies of tribal leaders

\begin{tabular}{|c|c|c|c|}
\hline Indicator & Mean & S.D. & $\begin{array}{c}\text { Qualitative } \\
\text { Measure }\end{array}$ \\
\hline $\begin{array}{c}\text { 1. Executive } \\
\text { Leadership Capability }\end{array}$ & 3.19 & 0.69 & $\begin{array}{c}\text { Moderately } \\
\text { Capable }\end{array}$ \\
\hline $\begin{array}{c}2 . \\
\text { Leadership Capability }\end{array}$ & 3.27 & 1.20 & $\begin{array}{c}\text { Moderately } \\
\text { Capable }\end{array}$ \\
\hline $\begin{array}{c}3 . \quad \text { Judicial } \\
\text { Leadership Capability }\end{array}$ & 3.32 & .094 & $\begin{array}{c}\text { Moderately } \\
\text { Capable }\end{array}$ \\
\hline Overall mean & 3.32 & 0.94 & $\begin{array}{c}\text { Moderately } \\
\text { Capable }\end{array}$ \\
\hline
\end{tabular}

The result of assessment on executive leadership capability across competence in planning, organizing, directing, coordinating, and controlling is more or less comparable, with a qualitative description of moderately capable. Some planning activities include management planning, negotiating, entering into, and signing contracts, planning programs and preparing annual budgets. Organizing activities include hearing cases peacefully and settling disputes amicably; maintaining peace and order, and even conducting rescue operations in times of disasters. Supervising capability cover activities related to the implementation of the provisions of the CADT, activities that promotes the general welfare, economic growth and development of the tribal barangay organizations. Directing activities include presiding over meetings, maintaining peace and order, and delivery of basic services among few. Coordinating activities include bringing together the general assembly for the preparation of barangay plans and programs and other related activities. Lastly, controlling capability includes protecting matters relative to the ancestral domains; consulting with the council of elders, controlling and maintaining public order, appointing or replacing officers and fund disbursement. The result revealed that tribal leaders are moderately capable in performing their executive leadership functions; however, they still need more training along this line for effective and efficient implementation of the various activities in the ancestral domain.

Legislative leadership capability was measured using two indicators: legislating local ordinances necessary to discharge responsibility and enacting ordinances that promotes the general welfare of the tribal barangay. The mean scale was 3.27 with a qualitative description of moderately capable. The result indicates that the tribal leaders are moderately capable in legislating ordinances necessary to discharge the responsibility conferred them; and to enact ordinances that promote general welfare, especially on matters in the implementation of the Indigenous Peoples Rights Act of 1997. This result was supported by the key informants, who said that they still need some help to improve their knowledge and skills on legislating ordinances for their organization.

Overall, Judicial Leadership Capability has a scale of 3.32 which has a qualitative description of moderately capable. This means that across the four indicators of judicial functions, tribal leaders can chair the Peace and Order Council/Council of Elders in hearing cases and bringing about acceptable, peaceful and amicable settlement. They are also moderately capable in mediating conflicts, making fair judgment/decision in accordance with customary/ constitutional laws, and in endorsing to higher court cases that needs extra judicial processes. Overall, Ayangan tribal leaders are moderately capable in judicial leadership; they can discharge basic judicial role/function but still needs improvement in discharging their leadership capability.

\subsection{Effectiveness of CADT as an Empowerment Mechanism}

The effectiveness of CADT as an empowerment mechanism was measured using the following indicators: recognition of ancestral domain, self-governance and empowerment, social justice, and cultural integrity. These indicators have a mean scale ranging from 3.18 to 3.32 which has a qualitative description of moderate.

Table 3: Effectiveness of CADT as an Empowerment Mechanism in the Ancestral Domain

\begin{tabular}{|c|c|c|c|}
\hline $\begin{array}{c}\text { Effectiveness of } \\
\text { CADT as } \\
\text { Mechanism for } \\
\text { Empowerment }\end{array}$ & Mean & S.D. & $\begin{array}{c}\text { Qualitative } \\
\text { Measure }\end{array}$ \\
\hline $\begin{array}{c}\text { Recognition of } \\
\text { Ancestral Domain }\end{array}$ & 3.32 & 0.99 & Moderate \\
\hline Social Justice & 3.18 & 0.95 & Moderate \\
\hline Cultural Integrity & 3.25 & 0.98 & Moderate \\
\hline Self-Governance & 3.18 & 0.94 & Moderate \\
\hline Overall Mean & 3.25 & 0.97 & Moderate \\
\hline
\end{tabular}

The result indicates that CADT is only moderately effective in determining the rights of stakeholders, ownership, possession and utilization resources; resolution of land conflicts in accordance with customary laws; protection of flora and fauna, watershed areas, and other reserves; regulating the entry of migrant settlers and organizations into the ancestral domain.

The CADT as empowerment mechanism for social justice was moderately effective. It is moderately effective in eliciting participation to cultural festivals, congresses and others, enforcement of laws to preserve, maintain and restore ecological balance and in reconciling related laws and in launching programs/projects to preserve and promote cultures, and documenting indigenous knowledge systems and practices.

The CADT, as an empowerment mechanism in ensuring cultural integrity is moderately effective, especially in coordinating the Alternative Learning Systems (ALS), granting Certificates of Confirmation, scholarship, and other benefits; practicing and documenting customary laws; strengthening collaboration with civil society organizations; developing learning materials with IPs and partner stakeholders; and accelerating the IP involvement in international advocacy initiatives.

Finally, the CADT is moderately effective in ensuring selfgovernance particularly in accessing grantees to Educational Assistance Program, and in identifying potentials leaders to Local Legislative Councils and policy making bodies, introducing livelihood and entrepreneurship, and delivering basic services, ensuring the inherent right of stakeholders to self-governance and self-determination; respect for the integrity of indigenous values, practices and institutions; and 


\section{International Journal of Science and Research (IJSR) \\ ISSN (Online): 2319-7064}

Index Copernicus Value (2013): 6.14 | Impact Factor (2015): 6.391

in guaranteeing rights to freely pursue economic, social and cultural development.

\subsection{Relationship of Tribal Leaders Aboriginal Tri- Functional Leadership Competencies and the Effectiveness of CADT as an Empowerment Mechanism in the AD}

The statistical analyses (Table 4) on the relationship of tribal leaders' leadership capability with the effectiveness of the CADT as an empowerment mechanism reveal significant correlation.

Table 4: Tribal leaders' aboriginal tri-functional leadership competencies and effectiveness of CADT as an empowerment mechanism in the ancestral domain of the Ayangan

\begin{tabular}{|c|c|c|c|c|c|c|}
\hline \multirow{2}{*}{\multicolumn{2}{|c|}{ Tribal Leaders Capability }} & \multicolumn{5}{|c|}{ Effectiveness of CADT as an Empowerment Mechanism } \\
\hline & & \multirow{2}{*}{$\begin{array}{c}\text { Recognition of } \mathrm{AD} \\
.280(* *)\end{array}$} & \multirow{2}{*}{$\begin{array}{c}\text { Social Justice } \\
.290(* *)\end{array}$} & \multirow{2}{*}{$\begin{array}{c}\begin{array}{c}\text { Cultural } \\
\text { integrity }\end{array} \\
.273(* *)\end{array}$} & \multirow{2}{*}{$\begin{array}{c}\begin{array}{c}\text { Self- } \\
\text { Governance }\end{array} \\
.229(* *) \\
\end{array}$} & \multirow{2}{*}{$\begin{array}{c}\text { Overall Level of } \\
\text { Effectiveness } \\
.295(* *)\end{array}$} \\
\hline Planning & $\mathrm{r}$ & & & & & \\
\hline & $\rho$ & $<.001$ & $<.001$ & $<.001$ & $<.001$ & $<.001$ \\
\hline \multirow[t]{2}{*}{ Organizing } & $\mathrm{r}$ & $.169(* *)$ & $.253(* *)$ & $.205(* *)$ & $.190(* *)$ & $.206(* *)$ \\
\hline & $\rho$ & .003 & $<.001$ & $<.001$ & .001 & $<.001$ \\
\hline \multirow[t]{2}{*}{ Supervising } & $\mathrm{r}$ & $.225(* *)$ & $.253(* *)$ & $.226(* *)$ & $.203(* *)$ & $.246(* *)$ \\
\hline & $\rho$ & $<.001$ & $<.001$ & $<.001$ & $<.001$ & $<.001$ \\
\hline \multirow[t]{2}{*}{ Directing } & $\mathrm{r}$ & $.254(* *)$ & $.348(* *)$ & $.317(* *)$ & $.271(* *)$ & $.311(* *)$ \\
\hline & $\rho$ & $<.001$ & $<.001$ & $<.001$ & $<.001$ & $<.001$ \\
\hline \multirow[t]{2}{*}{ Coordinating } & $\mathrm{r}$ & $.212(* *)$ & $.238(* *)$ & $.237(* *)$ & $.208(* *)$ & $.240(* *)$ \\
\hline & $\rho$ & $<.001$ & .000 & $<.001$ & $<.001$ & $<.001$ \\
\hline \multirow[t]{2}{*}{ Controlling } & $\mathrm{r}$ & $.314(* *)$ & $.350(* *)$ & $.310(* *)$ & $.286(* *)$ & $.335(* *)$ \\
\hline & $\rho$ & $<.001$ & $<.001$ & $<.001$ & $<.001$ & $<.001$ \\
\hline \multirow{2}{*}{$\begin{array}{c}\text { Overall Exec. Leadership } \\
\text { Capability }\end{array}$} & $\mathrm{r}$ & $.276(* *)$ & $.314(* *)$ & $.294(* *)$ & $.265(* *)$ & $.308(* *)$ \\
\hline & $\rho$ & $<.001$ & $<.001$ & $<.001$ & $<.001$ & $<.001$ \\
\hline \multirow[t]{2}{*}{ Legislative Capability } & $r$ & $.258(* *)$ & $.350(* *)$ & $.248(* *)$ & $.217(* *)$ & $.282(* *)$ \\
\hline & $\rho$ & $<.001$ & $<.001$ & $<.001$ & $<.001$ & $<.001$ \\
\hline \multirow[t]{2}{*}{ Judicial Capability } & $\mathrm{r}$ & $.257(* *)$ & $.327(* *)$ & $.273(* *)$ & $.247(* *)$ & $.293(* *)$ \\
\hline & $\rho$ & $<.001$ & $<.001$ & $<.001$ & $<.001$ & $<.001$ \\
\hline
\end{tabular}

The data suggests that if tribal leaders possess high level of leadership, CADT could become highly effective in the recognition of ancestral domain, particularly in the determination of lands, bodies of water, occupied, owned or used; developing and controlling lands traditionally occupied, owned or used; and in resolving land conflicts. The CADT could also be an effective instrument in protecting natural resources and in recognizing and promoting rights to ancestral domains. The provisions incorporated in the CADT could be used as an effective tool in negotiating terms and conditions for the exploration of natural resources; determining sacred places, traditional hunting and fishing grounds; staying and enjoying security of tenure, regulating the entry of migrant settlers and organizations and in the development program/projects.

The data also denote that if tribal leaders possess high level of leadership capability, the CADT could also be highly effective as a tool for social justice, especially in participation to cultural festivals, and congresses; enforcing laws to preserve, maintain and restore ecological balance, launching of programs/projects to preserve and promote cultures; and documenting indigenous knowledge, systems and practices.
A high leadership capability could induce the CADT to become a highly effective tool in ensuring cultural integrity especially in coordinating Alternative Learning Systems, granting Certificates of Confirmation for employment, scholarship, and other benefits, practicing and documenting customary laws, strengthening the collaboration with the civil society organizations; developing the learning materials with IPs and partner stakeholders; and accelerating the IP involvement in the international advocacy initiatives.

When tribal leaders are highly capable in planning, organizing, supervising, directing, coordination and controlling, the CADT could become a highly effective instrument for sustainable development and management of the CADT area. The result of the study further denotes that if the legislative leadership or judicial capabilities of the tribal leaders are high, the level of effectiveness of the CADT as an empowerment mechanism in also high. The CADT would then be an effective empowerment mechanism in terms of recognition of $\mathrm{AD}$, social justice, cultural integrity, selfgovernance.

Generally, the result denotes that if the aboriginal leadership capabilities of tribal leaders are high, the level of effectiveness of the CADT as an empowerment mechanism would also be high. 


\section{Conclusions and Recommendations}

Tribal leaders' aboriginal tri-functional leadership competencies are important in ensuring the effectiveness of the CADT as an empowerment mechanism. A high leadership capability particularly in planning, organizing, supervising, directing, coordinating and controlling enhances the effectiveness of the CADT as an empowerment mechanism in terms of the recognition of the ancestral domain, social justice, cultural integrity and self-governance.

Thus, to ensure the effectiveness of the CADT as an empowerment mechanism, there is a need to further develop and enhance the aboriginal tri-functional leadership competencies in executive, legislative, and judicial aspects, through trainings and seminars on organizational development and management and paralegal trainings on drafting ordinances and resolutions, as well as basic legal procedures that are applicable in hearing and deciding cases, or forwarding unresolved cases to higher authorities.

As anchored on the above premise, the study thus forwards that tribal leaders' aboriginal leadership competency is very important in the implementation of the CADT as an empowerment tool. A highly capable tribal leader in planning, organizing, controlling, directing, and coordinating could properly implement all activities and help make the CADT as an effective empowerment tool.

\section{References}

[1] Enters, T., and J. Anderson. 2000 "Rethinking the Decentralization and Devolution of Biodiversity Conservation." In Decentralization and Devolution of Forest Management in Asia and the Pacific. T. Enters, P. Durst, and M. Victor, eds. Pp.

[2] NCIP (National Commission for Indigenous People) 2007. Ayangan Claimbook of Certificate of Ancestral Domain Title.

[3] Mendoza, L. and J. Prill-Brett. 2012. Communal Land Management in the Cordillera Region of the Philippines. In "Land and Cultural Survival: The Communal Land Rights of Indigenous Peoples in Asia." http://aboutphilippines.ph/filer/ Communal-LandManagement-in-the-Cordillera-Region-chap02.pdf

[4] Osingat, L. 2007. "Anthro-Ethno-History of Nueva Vizcaya: The Ifugao (Ayangan) Account." The Ayangan Ancestral Domain Claimbook. National Commission on Indigenous People. Ancestral Domain Office, Diliman, Quezon, City, Philippines.

\section{Author Profile}

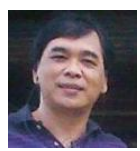

Marcelino T. Razalan, Jr. received his BS in Forestry, Master of Science in Rural Development and Forestry, and Ph.D. in Organization Development and Planning from the Nueva Vizcaya State University (NVSU); and Ph.D. in Resources Management - Environmental Management from Isabela State University (ISU). He is an Associate Professor V in the Department of Environmental Science and Ecotourism,
College of Forestry, NVSU, Bayombong, Nueva Vizcaya, Philippines. 